\title{
THE STUDY OF BILINGUAL MILIEU TOWARD THE STUDENT'S SPEAKING PERFORMANCE AT MODERN BOARDING SCHOOL
}

\author{
*1, Muchsonny ,Faisal Rahman², Rizky Hidayatullah ${ }^{3}$ \\ 1,2TK Pertiwi ,University of Sari Mulia Banjarmasin.3nstitut Agama Islam Ma'arif NU \\ Metro \\ Alamat: Jl. RA Kartini Purwosari Metro Utara Kota Metro \\ 085211583755 \\ e-mail: *1 muchsonny15@gmail.com,
}

\begin{abstract}
Abstrak
This research aims to analyze bilingual milieu toward the student speaking performance The research method uses qualitative research . The data collection techniques are used to obtain the data on questionnaires response and interviews. The instruments in this research used questionnaires. The data analysis Method using descriptive method. This research is conducted by describing the results of observation and diagnostic of the student's questioner and student's activities. This research conducted in Modern Islamic Boarding School because it gives special program to more develop English and Arabic, one of primary program to develop language with bilingual milieu. Because bilingual milieu make students habitually in speaking foreign language. and bilingual milieu can improve the student's performance in speaking English
\end{abstract}

\section{Keyword : Bilingual Milieu, Speaking Performance, Modern Boarding school}

\section{INTRODUCTION}

The performance of foreign language especially English as an international language has become more and more vital in fronting the world globalization. Indonesia, that is located in a strategic area, will get a strong effect of this appearance. Most of people especially the old generation might not feel the straight effect that caused by the world globalization. However, the young learner should ready as the next generation will be responsible for their better future since the world globalization in the free commerce has just beginning and portended agreement reached in short period of time(Hinchcliffe, 2014).

The vital of learning English could image from the fact that most scientific books are written in English and the students stimuli to understand those books. According the English curriculum, there are four basic skills, such as listening, speaking, reading and writing. The four basic skills supported by the learning of the language elements. They are structure, vocabulary, pronunciation, and spelling. Therefore, speaking is one of the vital of language skills that the students should master speaking includes skill of English. Moreover, the primary aim of learning 
and teaching English language is the students can communicate one another, then by speaking ability the students speak well(Rahmawati, 2017).

Speaking is one of the vital of language skills that the students should master in English speaking. Moreover, the primary aim of learning and teaching English language is the students can communicate one another, then by speaking ability the students speak well. Speaking is not only used to communicate each others, but also for express ideas, also it used to interaction with foreigner on business and commerce. As the student's speaking can explore their skill in English performance that caused speaking is primary of point students showing their capability in English performance(Derakhshan et al., 2016).

English Speaking also becomes frighten skill of the student because the student must claim all part of speaking skill such as vocabulary, spelling, pronunciation, these skill also be supported by student's confident to perform English speaking cause speaking need peer chatting in practice, because the factors above students select to delete this skill in their study of English(Fauzan, 2016).

The environment of English become solution the problems above because the environment that is dominant of English make student be familiar with English, and be accustomed to speak English although the student is less skill on speaking that finally used to speak English. The factor bilingual environment can improve speaking student such as many students use English as communication, there is friend who corrects when there is a mistake in speaking(Barac \& Bialystok, 2012).

There is several factors influence a students' speaking performance. The role of each factor often unifies with the students' confidence in performing speaking process. In Modern Islamic Boarding School, English and Arabic become the primary aim of teaching, so, in Modern Islamic Boarding School gives special program to more develop English and Arabic, one of primary program to develop language with bilingual milieu. Because bilingual milieu make students habitually speak second language (English \& Kitsantas, 2013).

The other supporting of study result are family's milieu, and society that student are living and school's milieu that student are learning. In multilingual society, multiracial, multicultural, and language cultural, social can influence of teaching language, for example students are everyday living in bilingual milieu then $\mathrm{s} /$ he can speak bilingual language although the dominant language is foreign language. Different with students that only are living in monolingual milieu than $\mathrm{s} /$ he only is able using monolingual, foreign only or second language only.

Bilingual is likely to occur when students have a positive view of their own ethnic indentify and of the target language culture, so bilingualism is likely students replace their foreign language with the second language, failing to develop full competence in their mother tongue(Bot, 2020).

It is widely accepted that those factors believe to be crucial for all levels of education. So, the researcher interested to focus on bilingual milieu. Based on the students' perception on their pre-research interview, Some problems can be 
indentified, they are: (1) the students have problem in comprehending English speaking (2) the students are lack of speaking English, (3) the student do not continue using English in bilingual milieu(Ormel \& Marcel Giezen, 2014).

Finally, the researcher wants to study what the factor of bilingual milieu can influence toward the students' speaking performance(Fitriani et al., 2015).

\section{RESEARCH METHODOLOGY}

The method of the research that was used in this research is descriptive qualitative and the aim of the research to describe the ability of student's speaking performance who live in the modern boarding school(Delmont \& Mason, 1997). the researcher take Modern boarding school of Roudlatul Qur'an Metro as place of the research. as proposed by Lexy (2007) that qualitative descriptive is research done to understand phenomenon experienced by research subject related to behavior, perceptions, actions, etc., holistically and by way of description of words and language, to a specific scientific context and by utilizing various scientific methods(Farr, 2008).

The research instruments were used interview and observation, the instrument is used the questionnaire of student's activity of Likert scale used four choices of answers(Hidayatullah et al., n.d.).

\section{RESULT AND DISCUSSION}

\section{Interview result related students' opinion.}

Table 4.1 student's perception about bilingual milieu in SMA TMI Roudlatul Qur'an

\begin{tabular}{|c|c|c|c|}
\hline $\mathrm{NO}$ & Students Response & Frequency & $\%$ \\
\hline 1. & Very Good & 24 & 38.09 \\
\hline 2. & Good & 39 & 61.91 \\
\hline 3. & Less good & 0 & 0 \\
\hline & Total & 63 & 100 \\
\hline
\end{tabular}

On table 4.1 number 1, there are $24(38.09 \%)$ student's perceptions about bilingual milieu are very good. $39(61.91 \%)$ student's perceptions about bilingual milieu are good. $0(0 \%)$ student's perceptions about bilingual milieu are bad.

Table 4.2 Students' perception about difficulty lived in bilingual milieu

\begin{tabular}{|l|l|c|c|}
\hline NO & Student Response & Frequency & $\%$ \\
\hline 1. & No & 22 & 34.92 \\
2. & Depend on & 26 & 41.26 \\
\hline
\end{tabular}




\begin{tabular}{|l|l|c|c|}
\hline 3. & $\begin{array}{l}\text { Situations } \\
\text { Yes }\end{array}$ & 15 & 23.80 \\
\hline & Total & 63 & 100 \\
\hline
\end{tabular}

On table 4.2 number 1, there are 22 (34.92\%) student's perceptions about bilingual milieu are not difficult. $26(41.26 \%)$ student's perceptions about bilingual milieu are depend of situations. 15 (23.80\%) student's perceptions about bilingual milieu are difficult.

Table 4.3 Students' perception about contributions of bilingual milieu toward their foreign language.

\begin{tabular}{|l|l|c|c|}
\hline NO & Student Response & Frequency & $\%$ \\
\hline 1. & Yes & 48 & 76.19 \\
2. & No & 4 & 6.35 \\
3. & Probably & 11 & 17.46 \\
\hline & Total & 63 & 100 \\
\hline
\end{tabular}

On table 4.3 number 1, there are 48 (76.19\%) student's perceptions about bilingual milieu are contribution their foreign language. 4 (6.35\%) student's perceptions about bilingual milieu are not contribution their foreign language. 11 (17.46 \%) student's perceptions about bilingual milieu are maybe contribution their foreign language.

Table 4.4 Students' perception about contributions of bilingual milieu toward their English

\begin{tabular}{|l|l|c|c|}
\hline NO & \multicolumn{1}{|c|}{$\begin{array}{c}\text { Student } \\
\text { Response }\end{array}$} & Frequency & $\%$ \\
\hline 1. & Yes & 51 & 80.95 \\
2. & No & 3 & 4.77 \\
3. & Probably & 10 & 15.87 \\
\hline \multicolumn{2}{|c|}{ Total } & 63 & 100 \\
\hline
\end{tabular}

On table 4.4 number 1, there are 51 (80.95\%) student's perceptions about bilingual milieu are contribution their English. 3 (4.77\%) student's perceptions about bilingual milieu are not contribution their English. 10 (15.87\%) student's perceptions about bilingual milieu are maybe contribution their English.

Table 4.5 Students' perception about contributions of bilingual milieu toward their English speaking 


\begin{tabular}{|l|l|c|c|}
\hline NO & \multicolumn{1}{|c|}{$\begin{array}{c}\text { Student } \\
\text { Response }\end{array}$} & Frequency & $\%$ \\
\hline 1. & Yes & 44 & 69.84 \\
2. & No & 2 & 3.18 \\
3. & Probably & 17 & 26.98 \\
\hline & Total & 63 & 100 \\
\hline
\end{tabular}

On table 4.5 number 1, there are 44 (69.84\%) student's perceptions about bilingual milieu are contribution their English speaking. $2(3.18 \%)$ student's perceptions about bilingual milieu are not contribution their English speaking. 17 (26.98\%) student's perceptions about bilingual milieu are maybe contribution their English speaking. Table 4.6 Students' perception about Motivation study in bilingual milieu

\begin{tabular}{|c|c|c|c|}
\hline $\mathrm{NO}$ & Student Response & Frequency & $\%$ \\
\hline 1. & Supporting their & 20 & 31.74 \\
\hline & English Speaking & & \\
\hline 2. & Improving their & 14 & 22.22 \\
\hline \multirow[t]{3}{*}{3.} & English & 29 & 46.03 \\
\hline & Other factor & & \\
\hline & Total & 63 & 100 \\
\hline
\end{tabular}

On table 4.6 number 1 , there are $20(31.74 \%)$ student's perceptions about motivation study in bilingual milieu school because supporting their speaking. $14(22.22 \%)$ student's perceptions about motivation study in bilingual milieu school because improving their English. 29 (46.03) student's perceptions about motivation study in bilingual milieu school because other factor.

Table 4.7 Students' perception about live in bilingual milieu

\begin{tabular}{|c|c|c|c|}
\hline $\mathrm{NO}$ & Student Response & Frequency & $\%$ \\
\hline 1. & Yes & 25 & 39.68 \\
\hline 2. & No & 22 & 34.92 \\
\hline 3. & $\begin{array}{l}\text { Depend on } \\
\text { situations }\end{array}$ & 16 & 25.40 \\
\hline & Total & 63 & 100 \\
\hline
\end{tabular}

on table 4.7 number 1, there are 25 (39.68\%) student's perceptions comfortable lived in bilingual milieu. $22(34.92 \%)$ student's perceptions 
not comfortable lived in bilingual milieu. 16 (25.40\%) student's perceptions depend of situations comfortable lived in bilingual milieu. Table 4.8 Students' perception about understood between English and Arabic

\begin{tabular}{|c|c|c|c|}
\hline NO & Student Response & Frequency & $\%$ \\
\hline 1. & English & 17 & 26.98 \\
\hline 2. & Arabic & 33 & 52.38 \\
\hline 3. & $\begin{array}{l}\text { Depend on } \\
\text { situations }\end{array}$ & 13 & 20.64 \\
\hline & Total & 63 & 100 \\
\hline
\end{tabular}

On table 4.8 number 1 , there are $17(26.98 \%)$ student's perceptions understood about English. 33 (52.38\%) perceptions understood about Arabic. 13 (20.64\%) perceptions understood between English and Arabic.

Table 4.9 the students' perceptions about method that used in bilingual milieu

\begin{tabular}{|l|l|c|c|}
\hline NO & \multicolumn{1}{|c|}{$\begin{array}{c}\text { Student } \\
\text { Response }\end{array}$} & Frequency & $\%$ \\
\hline 1. & Agree & 26 & 41.26 \\
2. & Disagree & 24 & 38.10 \\
3. & Unknown & 13 & 20.64 \\
\hline & Total & 63 & 100 \\
\hline
\end{tabular}

On table 4.9 number 1, there are $26(41.26 \%)$ student's perceptions are agree with direct method. 24 (38.10\%) student's perceptions are disagree with direct method. $13(20.64 \%)$ student's perceptions are unknown with direct method.

Table 4.10 students' perception about English after lived in bilingual milieu

\begin{tabular}{|l|l|c|c|}
\hline NO & \multicolumn{1}{|c|}{$\begin{array}{c}\text { Student } \\
\text { Response }\end{array}$} & Frequency & $\%$ \\
\hline 1. & No & 25 & 39.68 \\
2. & Yes & 23 & 36.51 \\
3. & Depend on & 15 & 23.81 \\
\hline
\end{tabular}




\begin{tabular}{|l|c|c|c|}
\hline & situation & & \\
\hline & Total & 63 & 100 \\
\hline
\end{tabular}

On table 4.10 number 1, there are $25(39.68 \%)$ student's perceptions about English is easily after their lived in bilingual milieu. 23 (36.51\%) student's perceptions about English is difficult after their lived in bilingual milieu. $15(23.81 \%)$ student's perceptions about depend situation about difficulty of English(Wirawan, 2019).

\section{CONCLUSION}

Based on the discussion, It can be concluded that the students' bilingual milieu of speaking performance is as an affective base that must be considered within English language instruction. Then, bilingual milieu is medium to improve the students' English speaking. Those all are described from this following:

Positive perceptions about bilingual milieu more than negative perception about bilingual milieu, so the writer concluded bilingual milieu is good factor for foreign language.

Positive perception about used direct method in bilingual milieu more than negative perception, so the writer concluded direct method is suitable method for bilingual milieu.

The student perception about bilingual milieu is problem solving toward difficulties foreign language is more than not, so the writer concluded bilingual milieu is one of problem solving about difficulties of foreign language specially English speaking .

The suggestion for the participants should construct their confident toward speaking performance. It is clear that speaking is as a communication production of performance. The participants mostly need to be able in interaction and comprehend foreign. Indeed, they must be able to improve their capability of speaking performance.

The teacher should consider the students' affective base in instruction process. In response to the base, the teacher can more improve their capability of students to increase their English speaking performance.

The further researcher who wants to conduct the related research should be mostly intensive and more deepen to learn about bilingual milieu.

\section{REFERENCES}


Barac, R., \& Bialystok, E. (2012). Bilingual Effects on Cognitive and Linguistic Development: Role of Language, Cultural Background, and Education. Child Development. https://doi.org/10.1111/j.1467-8624.2011.01707.x

Bot, K. De. (2020). A bilingual production model: Levelt's "speaking" model adapted. In The Bilingualism Reader. https://doi.org/10.4324/9781003060406-37

Delmont, S., \& Mason, J. (1997). Qualitative Researching. The British Journal of Sociology. https://doi.org/10.2307/591613

Derakhshan, A., Khalili, A. N., \& Beheshti, F. (2016). Developing EFL Learner's Speaking Ability, Accuracy and Fluency. English Language and Literature Studies. https://doi.org/10.5539/ells.v6n2p177

English, M. C., \& Kitsantas, A. (2013). Supporting Student Self-Regulated Learning in Problem- and Project-Based Learning. Interdisciplinary Journal of Problem-Based Learning. https://doi.org/10.7771/1541-5015.1339

Farr, B. C. (2008). Designing Qualitative Research. In Transformation: An International Journal of Holistic Mission Studies. https://doi.org/10.1177/026537880802500310

Fauzan, U. (2016). Enhancing Speaking Ability of EFL Students through Debate and Peer Assessment. EFL Journal. https://doi.org/10.21462/eflj.v1i1.8

Fitriani, D. A., Apriliaswati, R., \& Wardah. (2015). A Study on Student' s English Speaking Problems in Speaking Performance. Jurnal Pendidikan Dan Pembelajaran UNTAN.

Hidayatullah, R., Saputra, A. A., Amalia, D. R., \& Hasyim, A. A. (n.d.). Schema Activation Strategy in Reading Comprehension.

Hinchcliffe, V. (2014). English. In Enabling Access: Effective Teaching and Learning for Pupils with Learning Difficulties. https://doi.org/10.4324/9781315067780-9

Ormel, E., \& Marcel Giezen. (2014). Bimodal bilingual cross-langauge interaction: Pieces of the. In Running Head: Cross-Language Interaction.

Rahmawati. (2017). Improving English Speaking Ability. English Education Journal.

Wirawan, D. T. (2019). Social Accountability Process of Islamic Boarding School: Case Study of Sidogiri Pasuruan Islamic Boarding School. International Journal of Multicultural and Multireligious Understanding. https://doi.org/10.18415/ijmmu.v6i1.497

\section{Copyright Holder :}


(c) Name. (2020).

First Publication Right :

(C) Journal of English Development (JED)

This article is under:

(ㅇ)(1) (2) 